\title{
EVALUATION OF FNP FOR RC FRAME WITH BRICK INFILL
}

\author{
Amitkumar D J $^{1}$, G.N. Bhadri ${ }^{2}$, S.S.Dyavanal ${ }^{3}$ \\ ${ }^{1} P G$ Student @ Civil Engg Dept.BVBCET, Hubli, India \\ ${ }^{2}$ Professor@Mathematics Dept.BVBCET, Hubli, India \\ ${ }^{3}$ Professor@Civil Engg Dept.BVBCET, Hubli, India
}

\begin{abstract}
The RC multistoryedframe buildings are commonly built with brick masonry as infill walls. Window and entryway openings are unavoidable piece of the infill dividers. The vicinity of openings in infill dividers fundamentally lessens the parallel quality and solidness of RC casings. The fundamental natural period (FNP) of the building with infill panels depend on strength and stiffness of these infill. The strength and stiffness effect of the infill walls are not considered in any of the seismic codes across the world for calculating FNP. An attempt is made in the present paper to evaluate a new empirical formula by method of least squares $(M L S)$, considering the stiffness of the infill walls and number of bays and storeys. The analysis is carried using SAP v14.2 for gravity and seismic loading. Gravity analysis is carried out as per IS 456: 2000 code provisions. Seismic analysis is carried out as per IS 1893 (Part 1): 2002 procedures for multistoryed ordinary moment resisting frame (OMRF) buildings. All the models are constructed in seismic zone IV.The FNP results by MLS are compared with periods obtained from empirical formulae prescribed in seismic codes across the world.The authors conclude that, FNPs obtained by MLS are accurate than the FNPs calculated from the empirical formulae given in seismic codes considered in the paper.
\end{abstract}

KeyWords: Fundamental Natural Period, Infill Frame, Method of Least Square, OMRF, Seismic Code

\section{INTRODUCTION}

$\mathrm{RC}$ frames are infilled completely or partially by brick work infill boards with or without openings. Since these panels fundamentally improve both the strength and stiffness of the edge, their contribution is not considered in account it is because of the absence of information of the composite conduct of the infilled outline.In the present routine of basic configuration in India, brick work infill panels are dealt as non-structural component and their stiffness and strengthcontribution not considered. In fact the vicinity of infill divider changes the behaviour of the frame activity into truss activity, thus changing the transfer mechanism oflateral load pattern. Performance of buildings in the several earthquakes clearly showed that the vicinity of infill walls has noteworthy structural implications. So, we can't just disregard the auxiliary commitment of infill dividers especially in seismic districts where, the frame-infill interaction may bring about huge contribution in both stiffness and strength of the frame in spite in presence of openings. The design of structures to earthquakes demands safety of structures which is governed by the FNP. The FNPs of buildings are calculated by the empirical formulae specified in seismic codes for calculating design lateral forces and base shear. Seismic codes provide expressions for FNP that depends on the building material, building type and overall dimensions ${ }^{[14]}$. A new expression is derived on the basis of above comparison of fundamental natural period for RC Infill Frames with $35 \%$ openings ${ }^{[15]}$, which is near to the fundamental natural period obtained from the SAPv14.2.

\section{Objective and Scope}

The prime importance of the paper is to evaluate the empirical equations provided in current building codes for calculation of FNPs of buildings and recommend possible improvements i.e. compare the fundamental natural period obtained by MLS and empirical formula given in IS 1893 (Part 1): 2002 $2^{[1]}$ for various RC framed buildings configurations. Scope is limited to RC infill walls with $35 \%$ openings. Formula evaluated by MLS for FNP is applicable for building models. Following outlines the scope:

- Building up to 10 storeys and ten bays are considered.

- Buildings are regular in plan and symmetry.

- Buildings are OMRF RC frames.

\section{Methodology for Seismic Analysis}

Slab sections are modelled as rigid diaphragms and given membrane type behaviour. Beams and columns are modelled with centreline dimensions. Joints are rigid in nature hence zone factor is taken as one. The most common method of modeling infill walls is to use equivalent diagonal struts carrying axial compressive force. The width of diagonal strut (a) can be calculated with equation according to section 7.5.2 of FEMA-356.

Soil-structure interaction is not considered for the study. Footings are fixed condition at the base. 


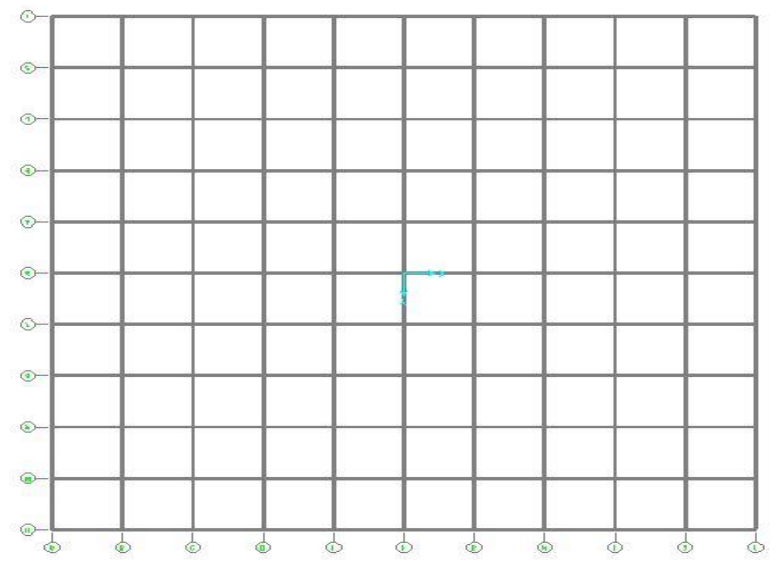

Fig.1: Plan of the Building

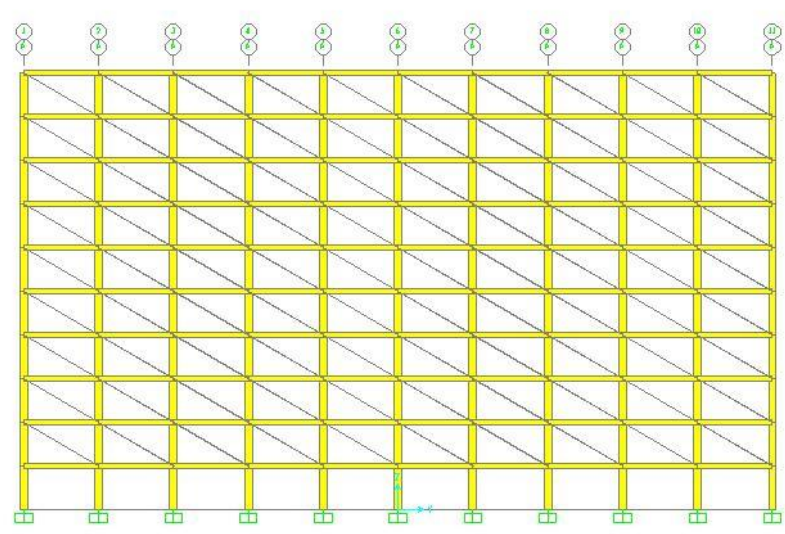

Fig.2: Side view of Infill Model

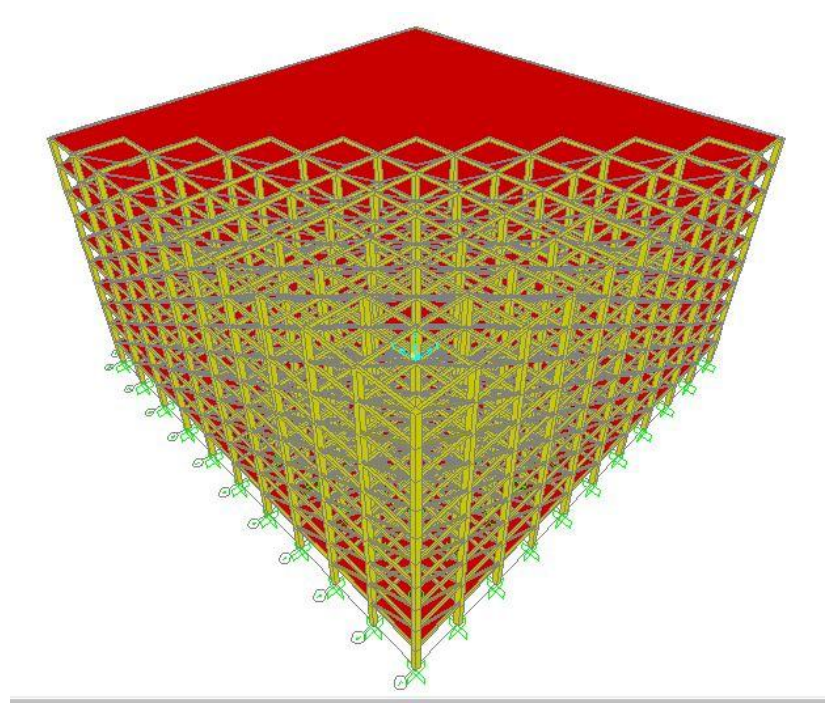

Fig.3: 3-D View of Infill Model

Fig.1, Fig.2 and Fig.3 shows the Plan of the building, Side view of infill frame model with struts and 3-D model of the infill frame model respectively.
Table 1: Building Description

\begin{tabular}{|l|l|}
\hline No of bays in X direction & 10 \\
\hline No of bays in Y direction & 10 \\
\hline Spacing along X direction & $6 \mathrm{~m}$ \\
\hline Spacing along Y direction & $6 \mathrm{~m}$ \\
\hline No of storeys & $\mathrm{G}+9$ \\
\hline Storey height & $3.5 \mathrm{~m}$ \\
\hline Parapet height & $1 \mathrm{~m}$ \\
\hline
\end{tabular}

Table 2: Material Properties

\begin{tabular}{|l|l|}
\hline Characteristic strength of concrete, $\mathrm{f}_{\mathrm{ck}}$ & $25 \mathrm{Mpa}$ \\
\hline Characteristic strength of steel, $\mathrm{f}_{\mathrm{y}}$ & $415 \mathrm{Mpa}$ \\
\hline Modulus of elasticity of concrete, $\mathrm{E}_{\mathrm{c}}$ & $25000 \mathrm{Mpa}$ \\
\hline Density of concrete & $25 \mathrm{kN} / \mathrm{m}^{2}$ \\
\hline Poisson's ratio of concrete & 0.3 \\
\hline Modulus of elasticity of steel, $\mathrm{E}_{\mathrm{s}}$ & $200000 \mathrm{Mpa}$ \\
\hline $\begin{array}{l}\text { Modulus of elasticity of brick masonry, } \\
\text { E }\end{array}$ & $1067 \mathrm{Mpa}$ \\
\hline Density of brick masonry & $20 \mathrm{kN} / \mathrm{m}^{2}$ \\
\hline Poisson's ratio of brick & 0.2 \\
\hline
\end{tabular}

Equivalent static and response spectrum analyses arecarried out as per IS 1893 (Part-1) 2002 for each model using SAP 2000 v14.2. Seismic weight of building calculated using full dead load plus $25 \%$ of live $\operatorname{load}^{[1]}$. The Fundamental Natural period values obtained from Eigen value analyses are compared with Method of Least Squares and other Seismic codes across the world.

\section{RESULTS AND DISCUSSION}

An expression is derived by MLS:

$(0.4153+0.2141 \mathrm{n}) \mathrm{X}$

$$
\begin{aligned}
& {\left[\frac{M}{(m+1) K c+m K i}\right]^{\left(-0.014+0.0347 \mathrm{n}-0.0112 n^{2}+0.0014 n^{3}-0.00006 n^{4}\right)}} \\
& \mathrm{K}_{\mathrm{i}}=\text { Stiffness of wall } \\
& \mathrm{K}_{\mathrm{c}}=\text { Stiffness of column } \\
& \mathrm{m}=\text { No of bays }
\end{aligned}
$$

Where

$$
\begin{aligned}
& \mathrm{K}_{\mathrm{c}}=12 \mathrm{EI} / \mathrm{h} \\
& \mathrm{K}_{\mathrm{i}}=\frac{A E m}{L d} \cos ^{2} \vartheta
\end{aligned}
$$

Where,

$$
\begin{aligned}
& \mathrm{A}=\mathrm{C} / \mathrm{s} \text { area of diagonal stiffness } \\
& =\mathrm{W} \times \mathrm{t}
\end{aligned}
$$




$$
\begin{aligned}
& E_{m}=\text { Elastic modulus of masonry wall } \\
& t=\text { Thickness of infill wall } \\
& h=\text { Height of infill wall } \\
& L_{d}=\text { Diagonal length of Strut }
\end{aligned}
$$

Empirical formulas of some of the countries are listed below.

IS 1893 (Part 1): 2002 ${ }^{[1]}$ : The approximate FNP (Ta) in seconds of a moment-resisting RCC framed building with brick infill framesgiven by the empirical expression:

$$
T=\frac{0.09 \times h}{\sqrt{d}}
$$

Where, $\mathrm{h}$ is the height and $\mathrm{d}$ is lateral dimensionof building in meters.

IBC 2000 Edition ${ }^{[2]}$ : The building period can be estimated using the empirical formula:

$$
T a=C_{t} h_{n}^{3 / 4}
$$

Where, Ct varies from 0.020 to 0.035 depending on the type of resting system $h_{n}$ is the height of the building in feet.

An alternate formula is provided for steel and concrete moment frame buildings 12 storeys or less in height and with storey heights 10 feet or greater:

$$
\mathrm{Ta}=0.1 \mathrm{~N}
$$

Where, $\mathrm{N}$ is number of Storey.

Israeli Seismic Code (SI-413 1995) ${ }^{[3]}$ : Israeli seismic code (SI-413 1995) gives the expression of fundamental natural period,

$$
\mathrm{T}=0.49 h^{0.75}
$$

Code also recommends that fundamental natural period calculated by structural dynamic method shall not be greater than

$$
\mathrm{T}=0.068 h^{0.75}
$$

Iranian Code for Seismic Resistance Design (ICS) ${ }^{[4]}$ :In ICS, FNP T, is determined with Equation

$\mathrm{T}=0.08 H^{3 / 4}$ (concrete)

$$
\begin{aligned}
& \mathrm{T}=0.07 H^{3 / 4} \text { (steel) } \\
& \mathrm{T}=0.05 H^{3 / 4} \text { (other buildings) }
\end{aligned}
$$

Where, $\mathrm{H}$ is the height of the building.

Building Standard Law in Japan 1981 (BSLJ) ${ }^{[5]}$ :In BSLJ the FNP of the building, T, shall be determined by expression:

$$
\mathrm{T}=\mathrm{H}(0.02+0.01 \alpha)
$$

Where, $\mathrm{H}$ is height of building in meters. $\alpha$ is ratio of total height of steel construction to height of building. ( $\alpha=0$ for concrete $\& \alpha=1$ for steel). $\begin{array}{llllllllllllll}0 & 1 & 2 & 3 & 4 & 5 & 6 & 7 & 8 & 9 & 10 & 11 & 12\end{array}$

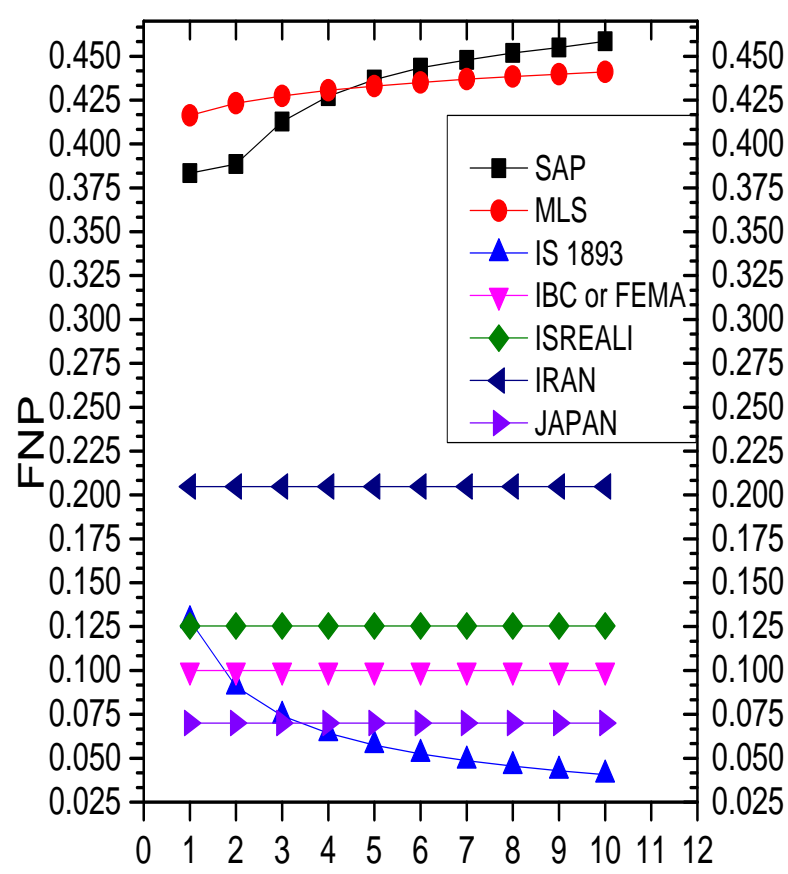

No. of Bays

Fig. 4 Variation of FNP for one storey

$\begin{array}{llllllllllllll}0 & 1 & 2 & 3 & 4 & 5 & 6 & 7 & 8 & 9 & 10 & 11 & 12\end{array}$

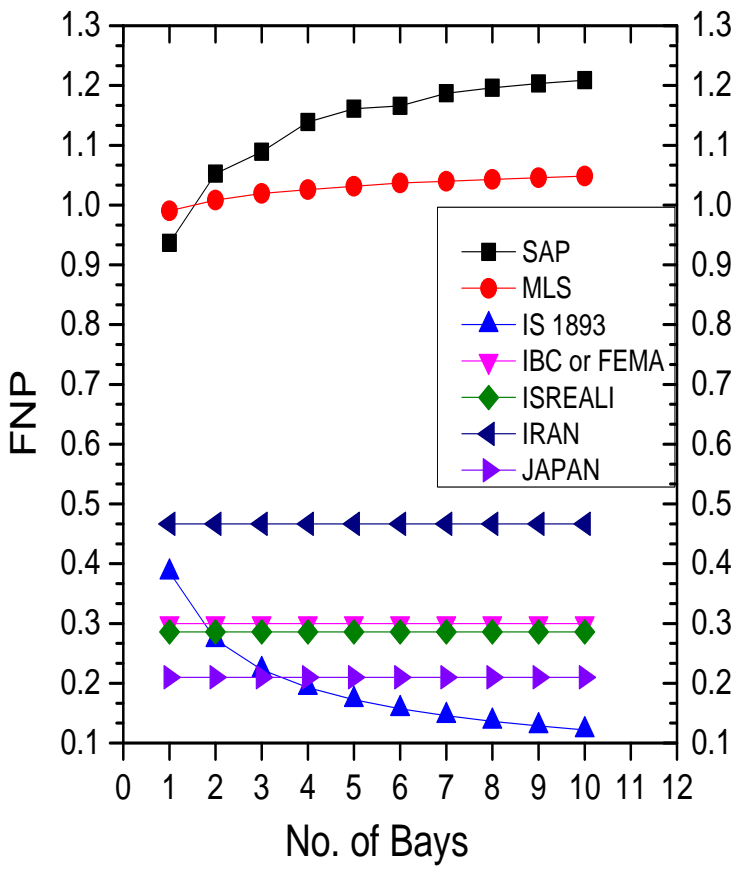

Fig.5 Variation of FNP for three storey 


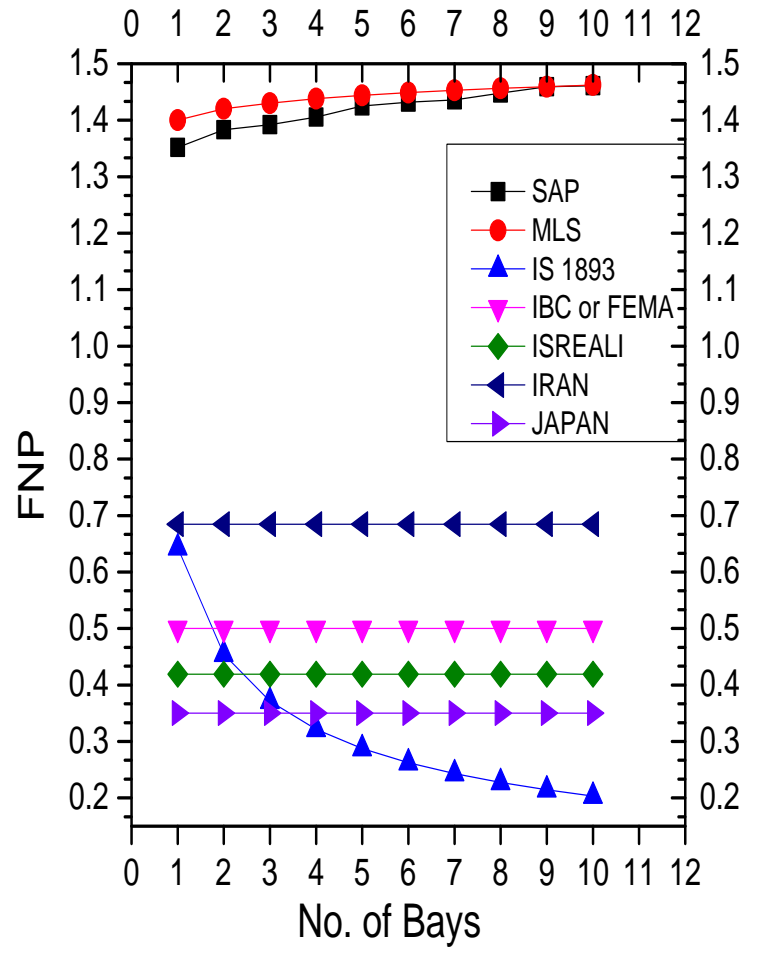

Fig.6 Variation of FNP for five storey

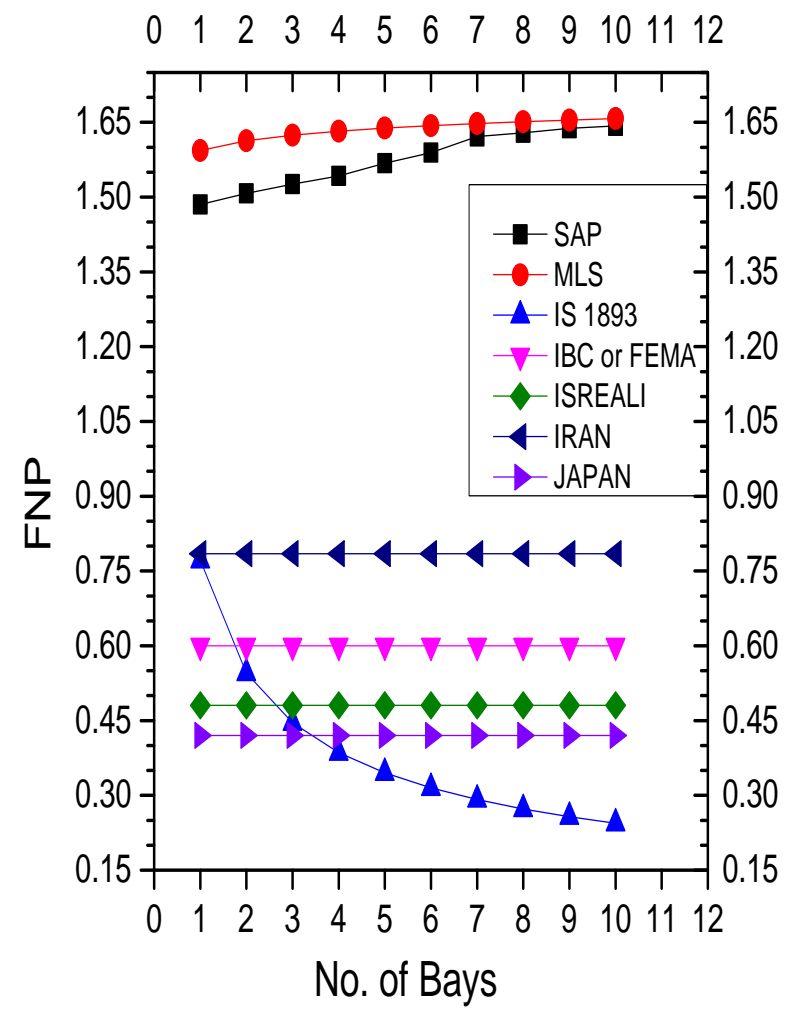

Fig.7 Variation of FNP for six storey

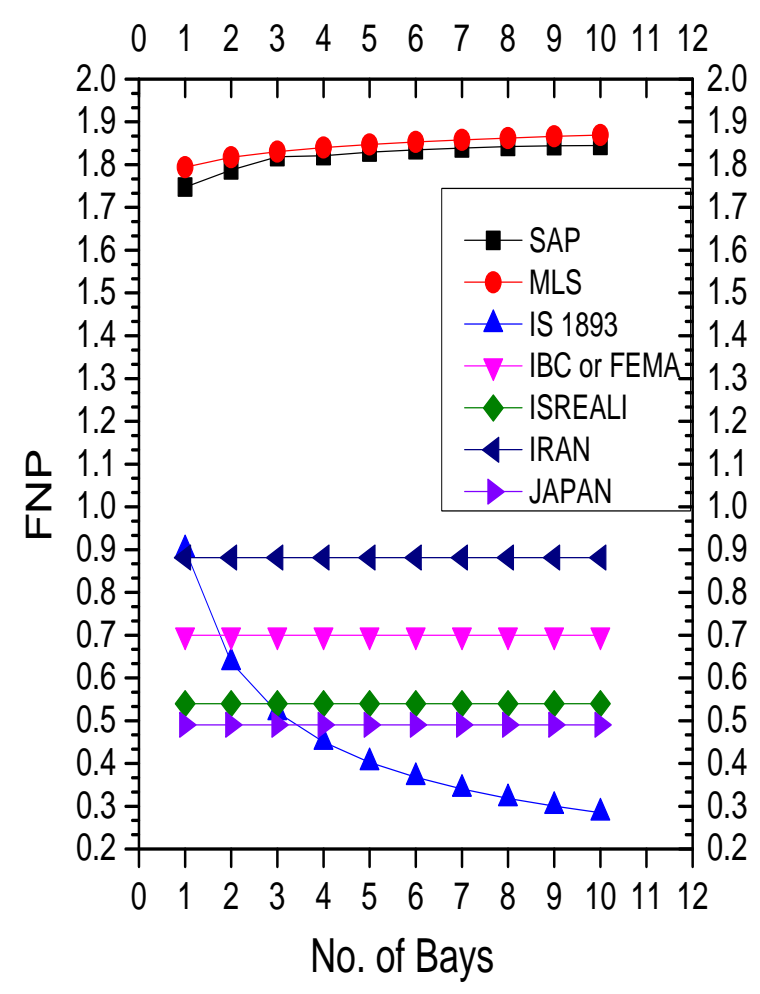

Fig.8 Variation of FNP for seven storey

$\begin{array}{llllllllllllll}0 & 1 & 2 & 3 & 4 & 5 & 6 & 7 & 8 & 9 & 10 & 11 & 12\end{array}$

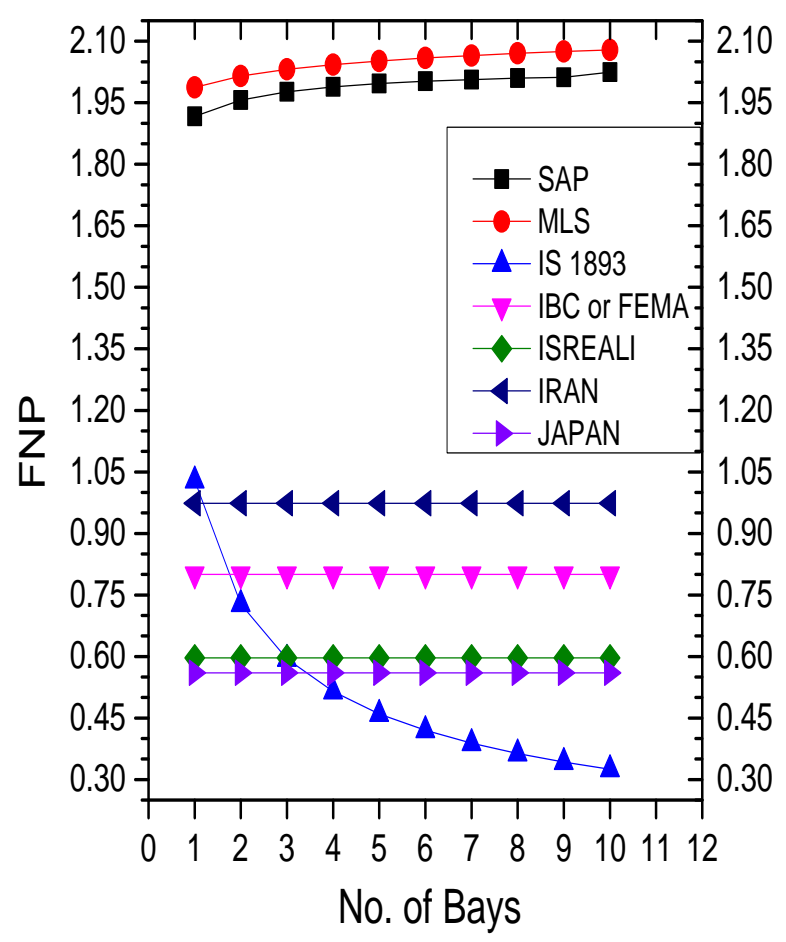

Fig.9 Variation of FNP for eight storey 
$\begin{array}{llllllllllllll}0 & 1 & 2 & 3 & 4 & 5 & 6 & 7 & 8 & 9 & 10 & 11 & 12\end{array}$

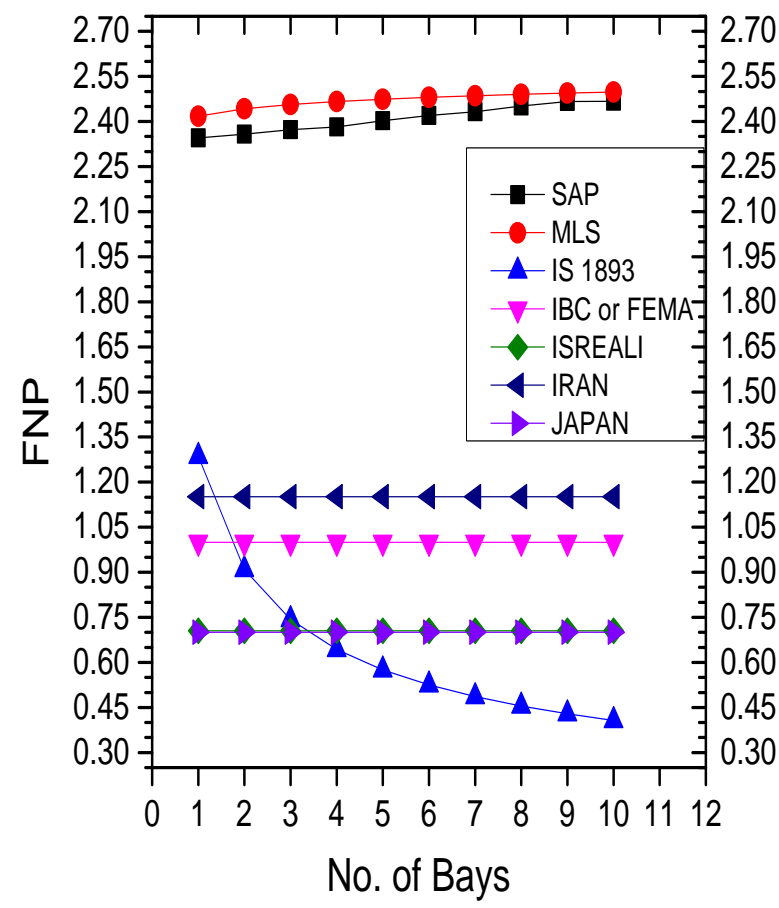

Fig.10Variation of FNP for ninestorey

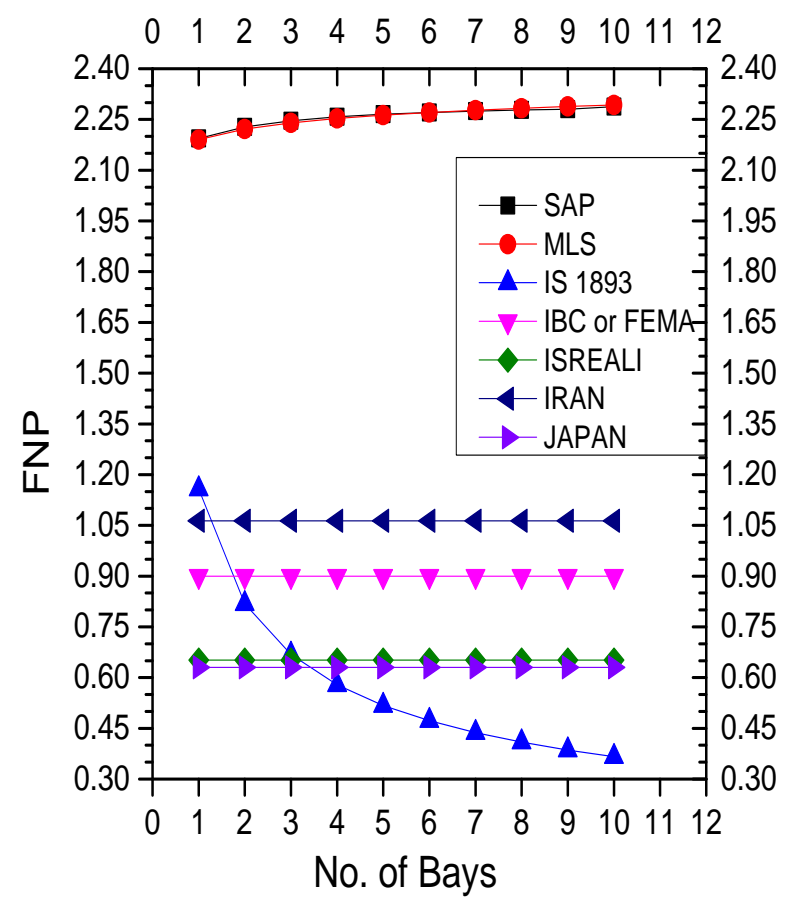

Fig.11 Variation of FNP for ten storey

For brick masonry infill frames theFNPvalues calculated from MLSare close to the natural periods obtained by SAP and rational than expressions given in IS 1893(Part 1): 2002, IBC 2000, Isreali, Iran and Japan country codes. The periods from MLS show an error of 5\%-8\% and the values of fundamental natural period given by MLS are slightly longer than the SAP up to five storey and further the values of MLS and SAP are same. Further the variances of IS 1893(Part 1): 2002 is showing an error of $66 \%-90 \%$. The IBC 2000 is showing an error of 66\%-78\%. Isreali and Iran codes are showing an error of $65 \%-76 \%$ and $40 \%-67 \%$ respectively. Time period calculated from Japan codes gives shorter time period with an error of 70\%-85\%.Considering infill walls in the analysis of RC framed building drastically reduces the FNP. The periods calculated as per the empirical formulae given in the codes differ significantly. The IS 1893(Part 1): 2002 and other seismic codes empirical formulae gives FNP which are almost half the computed values of MLS. Thus, neglecting infill walls leads to underestimating base shear and therefore unsafe design. The period values drastically changes as the no of bays increases in case of IS 1893(Part 1): 2002 whereas it remains same for MLS and SAP.

\section{CONCLUSIONS}

From the results discussed with respect to the building models considered leads to the following conclusions:

$>$ Fundamental natural periods obtained by Method of Least Squares are accurate than the FNPs calculated from the empirical expressions given in IS 1893 (Part I): 2002 and other country codes in this paper.

$>$ Derived equations for fundamental natural periods from Method of Least Squares are similar to SAP 2000 v.14.2.

> The base shear calculated using the Method of Least Squares are lesser compared to those by code expressions leading to economical design of buildings.

$>$ These formulas are applicable to any type of soil profile.

The expressions to calculate FNP mentioned in various seismic codes in India and across the world may be revised.

\section{REFERENCES}

[1] IS: 1893(Part1)-2002, Criteria for earthquake resistant design of structure, General Provision and Building.

[2] Seismic design for building codes 2000 USA (IBC 2000).

[3] Israeli Seismic Code (SI-413 1995).

[4] Iranian Code for Seismic Resistance Design of Buildings (ICS 1900).

[5] The Building Standard Law in Japan (BSLJ) seismic design provision for building codes (BSLJ 1981).

[6] S K Jain and C V R Murty. Proposed draft provision and commentary on Indian Seismic Code IS 1893 (Part 1).

Department of Civil Engineering, Indian Institute of Technology Kanpur.

[7] IS 456 - 2000, Code of Practice for Plain and Reinforced Concrete, Bureau of Indian Standards, New Delhi, India.

[8] Agarwal P. and Shrikhande M. 2006 "Earthquake Resistant Design of Structures" prentice - Hall of India Pvt Ltd. New Delhi, India.

[9] V.K ManikaSelvam, 1992 "An Introduction to Earthquake Analysis of Structures, Dhanpat Rai Publication, New Delhi, India. 
[10] RihanMaaze "Seismic Evaluation of Multistorey Buildings with Soft Storey", M.Tech Thesis, B.V. Bhoomaraddi College of Engineering \&Technology, Hubli, 2013.

[11] IS 875 (Part 1): 1987, Code of practice for Design loads (other than earthquake) for buildings and structures. Part I Dead loads - Unit weights of building materials and stored materials (second version), Bureau of Indian Standards, New Delhi, India.

[12] IS 875 (Part 2): 1987, Code of practice for Design loads (other than earthquake) for buildings and structures. Part II Imposed loads.

[13]Goel, K. R.and Chopra, K.A., Period formulas for moment-resisting frame Buildings, J. of Struct. Eng., ASCE, Vol.123, 1997,1454-1461.

[14] MdIrfanullah ,Vishwanath. B. PatilSeismic Evaluation of RC Framed Buildings with Influence of Masonry Infill Panel(IJRTE)ISSN: 2277-3878, Volume-2, Issue-4, September 2013.

[15] Praveen Rathod, Dr.S.S.DyavanalNon-Linear Static Analysis of G+6 Storeyed RC Buildings with Openings in Infill Walls. ISSN : 2248-9622, Vol. 4, Issue 9( Version 5), September 2014, pp.51-58 